\section{Zapomniana metafora AIDS}

Grzegorz Niziołek

TEKSTY DRUGIE 2018, NR 2, S. 354-368

DOI: $10.18318 /$ td.2018.2.22

Susan Sontag zwróciła uwagę, że metafory AIDS w większości mają charakter przednowoczesny. W 1988 roku, kiedy ukazała się jej książka AIDS i jego metafory, wciąż dyskutowana była etiologia choroby (mimo odkrycia wirusa) oraz sposoby zarażania się. Lawinowo narastała liczba chorych i wciąż nie znaleziono lekarstwa na powstrzymanie rozwoju choroby. Jedyną zalecaną skuteczną metodą zahamowania epidemii była zmiana trybu życia i zachowań seksualnych. Wobec bezsilności medycyny i ze względu na moralne podstawy prewencji powracały zapomniane metafory, w których choroba traktowana była jako coś zesłanego, a nawet zasłużonego; co było doświadczeniem o tyle znaczącym, że wcześniejsze wielkie epidemie XX wieku (np. grypy) nie miały już takiego charakteru. W przypadku AIDS choroba była traktowana jako inwazja obcych sił zagrażających społeczeństwu (wirus pochodził z Afryki, rozprzestrzeniał się wśród gejów) i jako kara, często dosłownie rozumiana jako kara Boża. Tak jak dżuma w średniowiecznej Europie. Podobna była też widzialność symptomów
NARODOWY PROGRAM ROZWOJU HUMANISTYKI

Artykułpowstałw ramach realizacji projektu

badawczego „Ekopoetyki historycznych katastrof i konfliktów w literaturze polskiejXXiXXI wieku. Perspektywa porównawcza", finansowanego przez Narodowy Program Rozwoju Humanistyki (nr projektu: $2 \mathrm{aH} 15005683$ ).

Grzegorz Niziołek prof. dr hab., pracuje na Wydziale Polonistyki UJ. Redaktor naczelny czasopisma „Didaskalia”. Autor Polskiego teatru Zagłady (2013) oraz monografii o twórczości Tadeusza Różewicza, Krystiana Lupy i Krzysztofa Warlikowskiego. 
zmieniających cierpiących ludzi w coś nieludzkiego, przerażającego, wstrętnego. Ciemne plamy mięsaka Caposiego były jak stygmat (we wczesnych filmach poświęconych AIDS właśnie ten symptom był utożsamiany z chorobą, zdradzał ukrywaną tożsamość, a rany na twarzy barona Harkonnena, homoseksualisty i czarnego charakteru w filmie Diuna Davida Lyncha z 1984 roku, kojarzyły się z gejowską zarazą). Chorych na AIDS porównywano do trędowatych. I, jak każda choroba przenoszona drogą płciową, wiązała się z czymś nieczystym, a zmaza - jak wiadomo - jest jedną z najbardziej pierwotnych metafor zła. Choroba ujawniała "grzeszny" tryb życia chorujących, zdradzała przynależność chorego do wspólnoty pariasów (homoseksualistów, narkomanów, Haitańczyków), stawała się zwielokrotnionym piętnem. „Niewinnych ofiar” AIDS było stosunkowo mało, tym większe odium spadało na „winowajców”, którzy stali się zagrożeniem dla społeczeństwa, dla jego zdrowia.

"Główną metaforą, przez którą rozumie się epidemię AIDS, jest metafora plagi” - pisała Sontag. „W przeciwieństwie do raka, rozumianego na sposób nowoczesny jako choroba, którą sprowadza na siebie (i jest przez nią demaskowana) jednostka, AIDS odbierany jest w sposób przednowoczesny jako choroba, którą ludzie sprowadzają na siebie jako jednostki, jak i członkowie «grupy wysokiego ryzyka» - tej neutralnie brzmiącej, biurokratycznej kategorii wskrzeszającej archaiczną ideę skażonej i osądzonej przez chorobę społeczności"2. Choroba traktowana jako plaga staje się - jak wyjaśnia dalej Sontag - „źródłem makabrycznych stereotypów”3. Plaga jest traktowana jako oznaka "moralnego upadku” i „politycznego schyłku”, mobilizuje więc nie do przeciwdziałania jej za pomocą środków medycznych, lecz domyślnie nawołuje do rozwiązań o charakterze politycznym, mających przeciwdziałać groźbie moralnej degrengolady. „Daily Mail” z 6 stycznia 1985 roku donosił w jednym z nagłówków: „Britain threatened by gay virus plague”.

Sontag w swoich rozważaniach nie uwzględnia jednak dostatecznie tego, że AIDS było nazywane nie tyle plagą, ile właśnie „plagą gejowską”. Zbyt metaforycznie traktuje analizowaną metaforę, traci z oczu jej konkretny kształt, a co za tym idzie - także istotny kontekst polityczny. A w mediach masowych taki właśnie komunikat przez pierwsze lata rosnących lawinowo

1 S. Sontag Choroba jako metafora. AIDS i jego metafory, przeł. J. Anders, Karakter, Kraków 2016, S. 124.

2 Tamże, s. 126.

3 Tamże. 
zachorowań na AIDS dominował. Inne dotknięte nią grupy (narkomani, hemofilitycy, haitańscy imigranci) zostały uznane bądź za niewinne, bądź za nie aż tak zagrażające społeczeństwu. Jak wyjaśnia Martha Grever ${ }^{4}$, kształtowanie społecznych postaw wobec AIDS w pierwszych latach epidemii zostało całkowicie oddane przez polityków mediom masowym. A te uruchomiły samoczynnie złowrogą falę homofobii na niebywałą skalę. Już w 1982 roku w amerykańskich mediach pojawiło się określenie gejowska plaga, na łamach „Newsweeka” ukazał się artykuł Homosexual Plague Strikes New Victims, użył go także w swym felietonie z 1983 roku wpływowy amerykański prawicowy felietonista, Patrick Buchanan, pisząc, że „biedni homoseksualiści [...] wydali wojnę naturze, a teraz natura bierze na nich okropny odwet"5. Dennis Altman w opublikowanej w 1986 roku książce AIDS in the Mind of America wyjaśniał, że powszechne przekonania na temat AIDS jako "gejowskiej plagi" ujawniały stopień upolitycznienia choroby ${ }^{6}$. Termin ten funkcjonował w brytyjskiej prasie nawet po tym, gdy National Union of Journalists potępiło stosowanie go. Już sam fakt, że dziennikarskie stowarzyszenie tej rangi publicznie wypowiedziało się na ten temat, świadczy najlepiej o skali zjawiska.

Metafora plagi była medialnie agresywniejsza i politycznie groźniejsza, niż wynika to $z$ analizy Sontag. I choć metafora ta ma niewątpliwie przednowoczesne źródła, została w przypadku AIDS zinstrumentalizowana przez nowoczesne strategie medialne w ramach nowoczesnych narzędzi dyskryminacji. Tylko takie złożenie w całość aspektów przednowoczesnych i nowoczesnych pozwala wniknąć w performatywny, czyli polityczny, wymiar metafory plagi w odniesieniu do AIDS. Przednowoczesny aspekt plagi był narzędziem świadomej manipulacji ze strony konserwatywnych mediów masowych, a nie tylko wyrazem „średniowiecznych" uprzedzeń względem seksualnej inności, na co Sontag również nie zwróciła dostatecznej uwagi. Metafora plagi z jednej strony miała mobilizować „nowoczesne” społeczeństwo przed zagrażającym mu "przednowoczesnym" złem (nowoczesna medycyna jest bezsilna wobec plagi), a z drugiej przywoływała „przednowoczesne” (czyli tradycyjne) wartości, aby przeciwstawić je „nowoczesnemu zepsuciu”. Określenie „gejowska plaga" było popularnym (spopularyzowanym przez media masowe) odpowiednikiem medycznego terminu GRID (Gay Related Immune Deficiency),

\footnotetext{
4 M. Grever Pictures of Sickness. Stuart Marshall's 'Bright Eyes', "October” 1987 Vol. 43, s. 110.

5 Cyt. za: D. Woubshet The Calendar of Loss. Race, Sexuality, and Mourning in the Early Era of AIDS, John Hopkins University Press, Baltimore 2015, S. 25.

6 D. Altman AIDS in the Mind of America, Anchor, New York 1986, s. 29.
} 
odnoszącego się do zespołu dwóch chorób (pneumocystozy i mięsaka Caposiego), na jakie zaczęli zapadać homoseksualni mężczyźni w Nowym Jorku i Kalifornii na początku lat 8o. Nieznana jeszcze wtedy etiologia choroby kazała środowisku medycznemu niejako zrzucić odpowiedzialność za zachorowanie na samych chorych. Nie bez znaczenia jest fakt, że medycyna chlubiła się w tym czasie całkowitym zwycięstwem nad wielkimi epidemiami zagrażającymi życiu. Bezsilność wobec AIDS była więc faktem niezbyt dla lekarzy wygodnym, zwłaszcza w wymiarze medialnym.

Wydaje się, że metaforze plagi można przeciwstawić inną, równie mocną i politycznie nośną, metaforę związaną z AIDS, która również pojawiła się w pierwszych latach epidemii. Metaforę Holokaustu. Zostaje ona wprowadzona w obieg komunikacji przez amerykańskich gejów żydowskiego pochodzenia. Omawiając metafory AIDS, Sontag całkowicie jednak pomija ten ważny krąg metafor związanych z Holokaustem. A już w połowie lat 80 . pojawiają się one w sposób wyraźnie ukształtowany. Niosą skrajnie odmienne skojarzenia niż metafora plagi, innym celom politycznym służą i pojawiają się w innym obiegu medialnym. Nie wiadomo, czy Sontag pominęła ten krąg metafor ze względu na ich etyczną niepoprawność (słowo „Holokaust” zostało uznane za określenie związane wyłącznie z zagładą Żydów i każde metaforyczne jego użycie było piętnowane przez środowisko żydowskie) czy też pragnęła skupić się - co bardziej prawdopodobne - przede wszystkim na metaforach służących społecznej opresji chorych. Wziąwszy pod uwagę znaczenie eseju Sontag i jego kanoniczny charakter, przywrócenie pamięci o pominiętej przez nią metaforze AIDS wydaje się konieczną korektą i suplementem. Zwłaszcza że metafora Holokaustu nie budowała, jak metafora plagi, napięcia między nowoczesnością a przednowoczesnością, przenosiła uwagę na nowoczesne metody dyskryminacji i jej polityczne narzędzia, stanowiła więc silną alternatywę dla metafory plagi używanej przez prawicowych publicystów, polityków i media masowe.

Jako jeden z pierwszych analogii między epidemią AIDS a zagładą europejskich Żydów użył Arnie Kantrowitz na łamach gejowskiego magazynu „The Advocate” w marcu 1983 roku w artykule Till Death Us Do Part'. Kantrowitz zwrócił uwagę na przypisanie gejom „nieczystości”, jaka charakteryzowała Żydów w nazistowskiej propagandzie. Stąd pojawił się zakaz kontaktów seksualnych „czystych” Aryjczyków z „nieczystymi” Żydami. Dla większości amerykańskiego społeczeństwa ta seksualna i moralna bariera między

7 A. Kantrowitz Till Death Us Do Part, "Advocate” 1983 No. 363 , s. 26. 
heteroseksualną większością a homoseksualną mniejszością wydawała się czymś gwarantowanym, oczywistym i naturalnym. I właśnie polityczne konsekwencje przyjmowania za dogmat istnienia tej bariery uruchomiły metaforę Holokaustu w odniesieniu do AIDS. Można powiedzieć, że skojarzenie to niejako wisiało w powietrzu, było już ukształtowane wcześniej - ruch gejowski w Stanach Zjednoczonych często odwoływał się do prześladowania homoseksualistów w III Rzeszy. Podczas nowojorskiej parady równości w 1973 roku wspominano Auschwitz i Buchenwald jako miejsca męczeństwa europejskich homoseksualistów ${ }^{8}$. Tego rodzaju nawiązania historyczne służyły mobilizacji politycznej środowiska amerykańskich gejów w walce o równe prawa. Na początku lat 8o. ukazały się wspomnienia Heinza Hegera Mężczyzna z różowym trójkatem. W 1980 roku odbyła się na Broadwayu premiera sztuki Bent Martina Sheermana opisująca prześladowania homoseksualistów w Niemczech w latach 30. i 40. i zarazem na wskroś przesiąknięta współczesną ideologią amerykańskiego ruchu gejowskiego. Sztuka mówiąca o prześladowaniach gejów w hitlerowskich Niemczech była równocześnie wezwaniem do coming outu (podczas gdy wiadomo, że represje dotknęły najpierw homoseksualistów, którzy nie ukrywali swojej orientacji). Różowy trójkąt, znak przypisany więzionym w obozach koncentracyjnych homoseksualistom, stał się ważnym symbolem w walce z dyskryminacją gejów w USA w latach 70.

Wyraźne nawiązania do Holokaustu pojawiły się w dwóch sztukach poświęconych tematyce AIDS, które miały premiery w Nowym Jorku w 1985 roku: As Is Williama M. Hoffmana oraz Normalnym sercu Larry'ego Kramera. Obaj autorzy byli gejami i Żydami. Larry Kramer pozostał wierny metaforyce Holokaustu w swojej płomiennej publicystyce politycznej przez kolejne lata, zbiór jego artykułów poświęconych AIDS ukazał się w 1989 roku pod tytułem Reports from the Holocaust. A pomysł napisania Normalnego serca zrodził się podczas wizyty pisarza w Dachau. Hoffman natomiast starał się zachowywać ostrożność w jej stosowaniu. W liście do „New York Times” wyjaśniał, że do snucia tego rodzaju paraleli skłoniło go doświadczenie utraty wielu bliskich mu osób, które wywołało pamięć o śmierci członków jego rodziny na Litwie i w Polsce z rąk Niemców i ich lokalnych sympatyków. Zauważa jednak, że do zwalczania kalifornijskich bigotów należy stosować broń odpowiednią do walki z niedoskonałą demokracją, a nie z państwem totalitarnym: „jak dotąd nie mamy do czynienia z obławami na gejów, narkomanów i ludzi chorych

8 Fragmenty nowojorskiej parady zostały utrwalone w filmie fabularnym Christophera Larkina A Very Natural Thing (1974). 
na AIDS, z obozami śmierci i systematycznym terrorem"9. Słowo „jak dotąd" było o tyle uzasadnione, że w debacie publicznej pojawiały się pomysły obowiązkowych testów, znakowania zakażonych, izolowania ich od zdrowego społeczeństwa. Natomiast Larry Kramer nie tylko pozostał wierny metaforze Holokaustu, ale także rozwinął ją w obszernym studium odwołującym się do politycznych pism Hannah Arendt. Co więcej, dla Kramera strategia nadużycia metafory stała się świadomie zastosowanym narzędziem politycznej perswazji - do tej kwestii jeszcze powrócę.

Obie przywołane premiery z 1985 roku stały się wielkim sukcesem, obie sztuki doczekały się też ekranizacji. Teatr, a szerzej performans, stał się, jak dowodzi w swojej książce Acts of Intervention. Performance, Gay Culture, and $A I D S^{10}$ David Román, ważnym narzędziem politycznego aktywizmu amerykańskich gejów w walce ze społecznymi i politycznymi skutkami epidemii AIDS. Służył nie tylko umacnianiu postaw politycznego aktywizmu, ale także przełamaniu komunikacyjnej bariery między społecznością gejowską a resztą społeczeństwa. Wkrótce też różowy trójkąt, ale odwrócony i opatrzony podpisem „Silence = Death", stanie się jednym z głównych symboli toczącej się wówczas politycznej walki w ramach ruchu ACT UP (Aids Coalition to Unleash Power), którego jednym z najważniejszych inicjatorów był właśnie Larry Kramer. Performans, jak wyjaśnia David Román, pomagał wedrzeć się w sferę publiczną zarządzaną przez Reaganowską politykę agresywnego liberalizmu ekonomicznego i obyczajowego konserwatyzmu oraz masowe media i religijnych fundamentalistów uznających się za moralną większość narodu. Aktywistyczny performans polityczny charakteryzuje się m.in. zdolnością nadawania nowych, wywrotowych sensów istniejącym pojęciom, przetwarzania symboli dyskryminacji w znaki afirmowanej tożsamości, możliwością ujawniania materialnych okoliczności swojego funkcjonowania oraz ucieleśnieniem własnej widowni w kontrze do idei widmowej "general public" przypisanej masowym mediom. Podobnym przekształceniom uległy metafory Holokaustu w obrębie gejowskiego performansu. To kolejny dowód na to, że metafory AIDS, ich ideologiczny wydźwięk oraz ich polityczne konsekwencje nie powinny być rozpatrywane poza kontekstem właściwych im obiegów medialnych.

9 W.M. Hoffman w odpowiedzi na list Lawrence'a D. Mass AIDS and the Holocaust, "New York Times" 21.10.1988.

10 D. Román Acts of Intervention. Performance, Gay Culture, and AIDS, Indiana University Press, Bloomington 1998. 
Pozornie wydaje się, że rację ma Hoffman, który wskazuje na niestosowność tworzenia zbyt daleko posuniętych analogii między Holokaustem a AIDS. Po pierwsze, demokratyczne Stany Zjednoczone nie są Niemcami rządzonymi przez Hitlera. Po drugie, AIDS jest katastrofą naturalną: „za Holokaustem stało wyrachowane ludzkie zło, za AIDS kryje się obojętny wirus"11. Choć i sam Hoffman przyznaje przecież, że niewiele brakowało, aby w niektórych stanach chorych ludzi uznano za przestępców godnych ukarania (w wielu stanach wciąż obowiązywało prawo przeciwko sodomii). Wbrew wyrażonym przez niego zastrzeżeniom metafora Holokaustu na dobre jednak związała się z historią AIDS. Co więcej, miała istotny wpływ na przebieg wielu kampanii politycznych. Pojawiała się w porządku zarówno dyskursywnym, jak i wizualnym. Dobrym przykładem może być sławna seria reklam Benettona z 1993 roku z wytatuowanym na męskim przedramieniu, pośladku i podbrzuszu napisem „H.I.V. positive”. Była to - jak pisze Jakub Janiszewski - „ironiczna gra z niegdysiejszymi pomysłami Williama F. Buckleya - amerykańskiego konserwatywnego publicysty, który w 1986 roku na łamach «New York Times» postulował tatuaże jako metodę znakowania zakażonych [...]”'12. Buckley proponował rodzaj „prywatnej” identyfikacji, która mogłaby uchronić przed zakażeniem ludzi zdrowych: „Każdy, u kogo wykryto AIDS, powinien być wytatuowany na przedramieniu, aby ostrzec innych przed użyciem wspólnej igły, oraz na pośladkach, by uchronić innych homoseksualistów przed staniem się kolejnymi ofiarami"13. Wobec istniejącego zagrożenia - postulował Buckley - „potrzebujemy cywilnego odpowiednika powszechnej służby wojskowej"14. Reklamy Benettona wzbudziły gwałtowne oburzenie we Francji, żądano ich usunięcia, traktowano je jako ponowną stygmatyzację „ofiar” AIDS. Ale francuski ACT UP uznał z kolei te żądania za wyraz pragnienia, aby chorych na AIDS zesłać ponownie w obszar społecznej niewidzialności, i dlatego poparł kampanię Benettona. Już ten przykład pokazuje, w jaki sposób wizualna metafora Holokaustu komplikowała pole politycznych napięć wokół AIDS.

11 W.M. Hoffman w cytowanym już liście do redakcji „New York Times”. J. Janiszewski Kto w Polsce ma HIV? Epidemia i jej mistyfikacje, Wydawnictwo Krytyki Politycznej, Warszawa 2013, s. 173. W.F. Buckley Crucial Steps in Combating the AIDS Epidemic; Identify All Carriers, "New York Times", 18.03.1986. 
Proponuję rozpatrzyć metaforę Holokaustu w odniesieniu do AIDS na trzech podstawowych płaszczyznach: psychologicznej, historycznej i politycznej. Te trzy płaszczyzny oczywiście przenikają się, tworząc złożony model metafory działającej w konkretnych okolicznościach społecznych i specyficznej sytuacji medialnej.

Jak już wspominałem, metafora Holokaustu pojawiła się w publicznej debacie na temat AIDS dzięki artystom, aktywistom i publicystom gejowskim żydowskiego pochodzenia. Większość z nich uważała tego rodzaju skojarzenie za coś nieuniknionego, związanego najczęściej z historią rodzinną, doświadczeniami z dzieciństwa. Pisał o tym we wstępie do As Is Hoffman:

Historie Holokaustu przychodziły mi do głowy. Większość mojej rodziny w Europie została zgładzona podczas wojny. Z tego co wiem, nie trafili nigdy do obozów koncentracyjnych, ale zostali zamordowani na ulicy przez swoich polskich i litewskich sąsiadów. Intelektualnie wiem, że epidemia nie jest Holokaustem, ale nie mam innego doświadczenia masowej śmierci oraz publicznej obojętności i brutalności, aby tworzyć porównania. ${ }^{15}$

A tak o swoim doświadczeniu AIDS opowiada Daniel Wolfe, gejowski aktywista:

Coraz wyraźnej czuliśmy, że jesteśmy w getcie. Dla mnie, jako Żyda, skojarzenie z gettem warszawskim było automatyczne. Pamiętałem z opowieści ocalonych, że tych, którym zdarzało się przekraczać mur, bo coś szmuglowali albo taką mieli pracę, wielkim zdumieniem napawało odkrycie, że poza granicami getta toczy się inne życie. W Nowym Jorku lat 8o. czułem to samo. Miałem 26 lat, a moi znajomi umierali. Rodzice mojego najlepszego przyjaciela wyrzucili go z domu, zostałem jego pielęgniarzem. Nie radziłem sobie ani z tą rolą, ani z tym, że umarł. AIDS był wszędzie wokół mnie, ale kiedy szedłem do pracy, do szanownego Foreign Policy Insitute, gdzie zajmowałem się polityką bliskowschodnią - nagle wszystko znikało. Tam AIDS znikało. Przekraczałem mur, żyłem w dwóch niepowiązanych rzeczywistościach. ${ }^{16}$

15 W.M. Hoffman As Is, Vintage Books, New York 1985, s. XIII. 
Podłoże metafory było więc afektywne, związane z opisywanym przez Marianne Hirsch syndromem postpamięci, transgeneracyjnym przekazem traumy. A transmisja traumy mogła być o tyle silniejsza, że dotyczyła dzieci homoseksualnych, zmagających się z homofobią społeczeństwa, naznaczonych odrębnym doświadczeniem traumatycznym (Kramer wspomina, że dopiero wieloletnia terapia pomogła mu zaakceptować swoją homoseksualność, a trudność zaakceptowania jego homoseksualnej orientacji przez kochającego go brata była źródłem osobistego dramatu). W dodatku orientacja homoseksualna często była przyczyną konfliktu z tradycją kultury żydowskiej, z judaizmem. Sporo o tym pisze Larry Kramer, poświęcił nawet temu swoją kolejną - po Normalnym sercu - autobiograficzną sztukę, The Destiny of Me. Zarówno w Normalnym sercu, jak i w As Is nawiązania do Holokaustu pojawiają się w intymnych scenach, partnerzy żydowskich kochanków nie są Żydami, reagują z niecierpliwością, dostrzegając albo jakąś przykrą niestosowność $\mathrm{w}$ takich nawiązaniach, albo równie trudne do zniesienia eksponowanie żydowskiej tożsamości. Zwracam uwagę na to afektywne, intymne i konfliktowe pole wyłonienia się metafory Holokaustu, ponieważ pozbawiało ją to politycznej instrumentalizacji, którą obarczona była metafora plagi. Ważne też jest to, że pojawiała się ona poprzez medium dramatu i teatru, poza kontekstem mediów masowych, ujawniała dzięki temu swoje usytuowanie kulturowe i, co więcej - krytycznie eksponowała niepełną przystawalność do rzeczywistości AIDS. Jerry Weeds, bohater Normalnego serca i porte-parole autora, doskonale wie, że jest natarczywy i nieznośny w narzucaniu otoczeniu analogii między Holokaustem a sytuacją gejów w dobie AIDS, stara się jednak dostarczać argumentów politycznych. W inscenizacji dramatu Kramera w nowojorskim Public Theatre akcji scenicznej towarzyszyły aktualizowane wciąż napisy na ścianach, informujące o liczbie zachorowań, o zaniżaniu statystyk, o wysokości publicznych dotacji na walkę z AIDS w poszczególnych miastach (demaskowano w ten sposób postawę burmistrza Nowego Jorku, Edwarda Kocha, wobec AIDS), o liczbie artykułów na temat AIDS w dużych dziennikach (zwracając uwagę na znaczące milczenie niektórych gazet). Teatr stawał się przestrzenią alternatywnej komunikacji społecznej.

Na jednej ze ścian znajdował się dłuższy napis:

Istniały dwie alternatywne strategie, które mogły być użyte przez żydowską organizację, żeby nakłonić amerykański rząd do podjęcia działań na rzecz ginących Żydów w Europie. Mogła współpracować z przed- 
stawicielami rządu, starając się po cichu ich przekonać, że uratowanie Żydów powinno być jednym z głównych celów prowadzonej wojny, albo mogła wywierać presję na rząd do podjęcia kroków w celu ocalenia Żydów, poprzez publiczne zawstydzanie i jednoczenie opinii publicznej dla osiągnięcia tego celu.

The American Jewish Committee wybrał tę pierwszą i trzymał się jej kurczowo.

Od samego początku kryzysu żydowskiego komitet na każdy kolejny nazistowski gwałt odpowiadał, uprawiając swój tradycyjny styl dyskretnej, zakulisowej dyplomacji.

$\mathrm{Na}$ każde nowe, coraz gorsze zdarzenie komitet reagował, kontaktując się z jakimś innym urzędnikiem lub wracając do tych samych, aby zwrócić im uwagę na nową sytuację.

Żydowskie delegacje były zazwyczaj uprzejmie informowane, że sprawę traktuje się z „najwyższą powagą".

Próbowano wciąż wpłynąć na tych samych urzędników, aż wojna się skończyła.

Cytat z American Jewry during the Holocaust. Opracowane dla American Jewish Commission on the Holocaust, 1984, pod redakcją Seymoura Maksa Fingera. ${ }^{17}$

Przytaczam ten napis w całości, aby zwrócić uwagę na jego znaczenie dla konstruowania odbioru spektaklu, jego afektywnej polityki. Twórcy przedstawienia celowo nawiązali do toczącej się wówczas w Stanach Zjednoczonych debaty na temat współodpowiedzialności amerykańskiego rządu i amerykańskich mediów za zagładę europejskich Żydów. Towarzyszące temu zawstydzenie środowisk politycznych i opinii publicznej miało poniekąd zostać przekierowane na współczesną sytuację, w której znajdowano analogie do wydarzeń z przeszłości.

Analogie te należałoby ująć w dwóch kategoriach: współudziału czynnego i współudziału biernego. Metafora plagi przenosiła sprawczość na czynniki ponadludzkie i nie-ludzkie: naturę i Boga. Masowe media i politycy nie ponosili żadnej odpowiedzialności za rozwój epidemii. Metafora Holokaustu traktowała epidemię AIDS przede wszystkim w kategoriach politycznych, przypisując sprawczość politykom, dziennikarzom, lekarzom, środowiskom gejowskim. Metafora plagi czyniła z AIDS rodzaj społecznego spektaklu, który

L. Kramer The Normal Heart, A Plume Book, New York 1985, s. 21-22. 
był przez większość obserwowany z bezpiecznych pozycji (zwłaszcza w początkowym okresie epidemii), z dystansem i bez empatii. Metafora Holokaustu pozwalała zdemaskować tego rodzaju postawę społeczną, przypominając, że to właśnie bierna postawa bystanders (do których zaliczali się także politycy, międzynarodowe organizacje, kościoły) umożliwiła przeprowadzenie eksterminacji Żydów na tak masową skalę. A na zjawisko wytwarzania przez masowe media syndromu bystanders zwracali uwagę amerykańscy badacze Holokaustu ${ }^{18}$.

W tym okresie następowała znacząca reorientacja w badaniach nad zagładą Żydów, przesuwano punkt skupienia z relacji ofiara - sprawca na relację ofiara - bierni świadkowie (bystanders). Simon Watney we wstępie do drugiego wydania Reports from the Holocaust Kramera z 1990 roku cytował w zakończeniu Zagładę i nowoczesność Zygmunta Baumana ${ }^{19}$, która ukazała się rok wcześniej. Watney, podzielając stanowisko Kramera, że społeczna polityka wobec epidemii AIDS uprawiana przez rządy amerykański i brytyjski przybierała często cechy ludobójcze, odwoływał się do cytatu z książki Baumana, w którym była mowa o tym, że jedną z lekcji Holokaustu jest łatwość, z jaką większość ludzi w obliczu masowej zagłady potrafi uwolnić się od jakichkolwiek zobowiązań moralnych wobec cierpiących innych.

Metafora Holokaustu dla niektórych miała przede wszystkim wymiar osobisty, emocjonalny, afektywny (jak dla Hoffmana), dla Larry'ego Kramera wiązała się z polityczną analizą postaw, wydarzeń, medialnych przekazów. Kramer, angażując się aktywnie w walkę z AIDS, uważnie śledził wszystkie zaniedbania po stronie polityków, lekarzy, mediów, koncernów farmaceutycznych. Sygnalizował najpierw deficyt środków na prowadzenie badań, a następnie ich niewłaściwą dystrybucję. Porównywał nakłady na walkę z AIDS z dotacjami przeznaczonymi na zwalczanie innych, znacznie mniej groźnych i o mniejszym zasięgu, lokalnych epidemii. Krytykował niewłaściwe procedury wdrażania terapii eksperymentalnych. Zwracał uwagę na powściągliwość dziennika „New York Times” w relacjonowaniu wydarzeń związanych z rozpowszechnianiem się choroby. Przeprowadzone w połowie

18 Pisał o tym m.in. G.H. Hartman w swojej książce The Longest Shadow. In the Aftermath of the Holocaust, w rozdziale Public Memory and Its Discontents (Indiana University Press, Bloomington-Indianapolis 1996, s. 99-115).

19 S. Watney Forward. The Persistence of Memory, w: L. Kramer The Reports from the Holocaust: the Making of an AIDS Activist, Penguin Books, New York 1990, s. XXIV-XXV. 
lat 8o. analizy relacji medialnych ${ }^{20}$ potwierdzają racje Kramera. „New York Times", po pierwszych publikacjach na temat dziwnych chorób szerzących się wśród amerykańskich homoseksualistów, na niemal dwa lata zamilkł. Ponowne zainteresowanie tematem pojawiło się wówczas, gdy na AIDS zaczęły zapadać osoby spoza "grup podwyższonego ryzyka” - żony narkomanów, dzieci zarażonych kobiet, pacjenci po transfuzji krwi. Bariera między heteroseksualną większością a homoseksualną mniejszością okazała się nie aż tak szczelna. Wtedy dopiero „New York Times” aktywniej włączył się $\mathrm{w}$ rozpowszechnianie wiedzy na temat AIDS.

Kramer w swojej publicystyce wskazywał na różne formy i aspekty bierności, przyczyny i konsekwencje rozmaitych zaniedbań. Nie zawahał się też wytoczyć najpotężniejszego argumentu, że bierność wielu polityków, w tym Ronalda Reagana, nosi znamiona ludobójstwa. Epidemia AIDS prowadziła do zniszczenia amerykańskiej gejowskiej wspólnoty, ukształtowanej na wzór etnicznej mniejszości, co było przecież jawnym celem politycznym wielu prawicowych polityków i działaczy religijnych jeszcze przed wybuchem epidemii. A jak zauważyła Martha Nussbaum ${ }^{21}$, argumenty radykalnych konserwatystów na temat homoseksualizmu trafiały także do znacznej części (jeśli nie większości) społeczeństwa, która w innych sprawach nie zajmowała już tak skrajnego stanowiska i nie utożsamiała się z religijnym fundamentalizmem. Metafora plagi spełniała swoją funkcję, sprzyjając postawom obojętności (nie należy przecież mieszać się w wyroki boskie). A społeczna obojętność wobec „ofiar gejowskiej plagi” sprzyjała religijnym fundamentalistom, którzy wprost wyrażali przekonanie, że plaga ta pozwoli „rozwiązać” problem zgorszenia, jakie homoseksualiści wraz ze swoją emancypacją zaczęli wywoływać w sferze publicznej. Sprzeciwiano się dużym nakładom finansowym na poszukiwanie skutecznych leków na AIDS, ponieważ to oznaczałoby powrót uleczonych do dawnych "grzesznych" praktyk (popierano raczej badania nad szczepionką, która miała zabezpieczyć heteroseksualną większość przed rozszerzaniem się epidemii). Mimo że żaden poważny polityk nie odważył się zająć oficjalnie takiego stanowiska, wiele podejmowanych na najwyższym szczeblu decyzji politycznych sprzyjało niekontrolowanemu rozszerzaniu się

20 A.J. Baker The Portrayal of AIDS in Media: an Analysis of in the New York Times, w: The Social Dimensions of AIDS: Method and Theory, ed. by D.A. Feldman, T.M. Johnson, Praeger, New YorkLondon 1986, S. 179-191.

21 M. Nussbaum From Disgust to Humanity: Sexual Orientation and Constitutional Law, Oxford University Press, Oxford 2010, s. 2-3. 
epidemii. Na przykład na wniosek jednego z prawicowych senatorów, Jessego Helmsa, przegłosowano wniosek o zakazie wydawania publicznych funduszy na działania "promujące, wspierające i akceptujące homoseksualną aktywność" ${ }^{22}$, a w tym zakresie mieściła się przecież także kampania promująca "bezpieczny seks”.

Simon Watney, autor jednej z najważniejszych książek poświęconych politycznym aspektom AIDS, Policing Desire: Pornography, AIDS, and the Media, wydanej po raz pierwszy w $1987 \mathrm{roku}$, analizował w artykule pisanym w tym samym roku do czasopisma „October” społeczną dramaturgię „spektaklu AIDS”. Jego wnioski są zbieżne z tezami Kramera:

spektakl AIDS spokojnie i wytrwale rozpatruje możliwą perspektywę śmierci wszystkich zachodnioeuropejskich i amerykańskich gejów z powodu AIDS - w sumie, powiedzmy około dwudziestu milionów ludzkich istnień - bez cienia troski, żalu lub żałoby. ${ }^{23}$

Metafory Holokaustu pozwalały ujawnić barierę, jaka została stworzona wokół społeczności gejowskiej, a także procesy stygmatyzacji, które usprawiedliwiały wszelkie postawy zarówno bierności, jak i wrogości. Zwracano uwagę na zjawisko śmierci społecznej poprzedzającej śmierć biologiczną, jaka dotknęła chorych na AIDS, zwłaszcza gejów, ponieważ to oni - według logiki metafory gejowskiej plagi - byli nie tylko winni własnemu losowi, ale także stawali się zagrożeniem dla większości. I nawet jeśli metafora ta była dla wielu nadużyciem, nie ulega wątpliwości, że w przypadku zarówno AIDS, jak i Holokaustu mamy do czynienia ze splotem, niebezpiecznie zacierających swoje granice, dyskursów: medycznego, politycznego, prawnego i moralnego. Podłożem takiego wymieszania dyskursów stawało się ideologicznie nacechowane pojęcie „natury”. Co prowadziło do przenikania się takich pojęć jak: choroba, przestępstwo, niemoralność, społeczna szkodliwość. Martha Nussbaum podkreśla, że „niemieckie przedstawienia Żyda znajdują się bardzo blisko sposobu opisywania gejów przez Paula Camerona, ponieważ w obu przypadkach następuje odwołanie do idei wrodzonego wstrętu, pomieszanego z wyobrażeniami zarażania i degeneracji”24.

E.I. Koch Senator Helms's Callousness towards AIDS Victims, „New York Times” 7.11.1987.

S. Watney The Spectacle of AIDS, "October" 1987 Vol. 43, s. 85. 
W obszernym eseju, który dał tytuł tomowi jego publicystki na temat AIDS, Kramer, pisząc o sytuacji amerykańskich gejów w dobie AIDS, odwołuje się do politycznych pism Hannah Arendt ${ }^{25}$. Przyjmuje za Arendt tezę, że szczególnie narażonymi na dyskryminację i eksterminację są wspólnoty, których status ekonomiczny i społeczny nie idzie w parze z realną polityczną sprawczością. Wzorem Arendt Kramer podejmuje się krytycznej oceny postaw dyskryminowanej i zagrożonej wspólnoty, która unika politycznego zaangażowania; pisze o zamożnych gejach znajdujących się w różnych ważnych publicznych instytucjach, niedziałających jednak na rzecz społeczności, do której należą. Zaleca wszystkim homoseksualistom studiowanie ku przestrodze historii Żydów. Metafora Holokaustu służy w tym wypadku pobudzaniu politycznej aktywności. Temu służy też nieposkromiona retoryka tekstu. Kramer nazywa San Francisco „gejowskim Izraelem”, amerykańskich biurokratów porównuje do urzędników Eichmanna, a gejowskie organizacje do Judenratów. Potrafi nazwać Ronalda Reagana Hitlerem, choć ostatecznie pisze, że „holocaust nie potrzebuje Hitlera, żeby być skutecznym"26. Zależy mu na jednym: żeby wzbudzić gniew gejowskiej społeczności, przypomnieć jej, że polityczną stawką są już nie tylko równe prawa, jak dekadę wcześniej, ale perspektywa przeżycia, przetrwania. Tego rodzaju retoryka może wzbudzać sprzeciw. Trudno jednak całkowicie odrzucić argument Kramera, że pogodzenie się z własną dyskryminacją ze strony gejów także miało wpływ na przebieg epidemii i jej zatrważające żniwo.

W przeciwieństwie do metafory plagi, która służyła umacnianiu się postaw bierności wobec AIDS zarówno wśród homoseksualnej, jak i heteroseksualnej społeczności, metafora Holokaustu miała działać aktywizująco na obie te grupy. Przenosiła uwagę z genezy choroby, która w mediach masowych (nie bez udziału reprezentantów środowisk medycznych, działaczy religijnych, polityków) powiązała ją z homoseksualistami i trybem ich życia, na jej polityczne znaczenia i konteksty. Kluczowa dla politycznej analizy wydarzeń związanych z AIDS i rozwoju gejowskiego aktywizmu metafora nie doczekała się solidnej monografii ani w ramach gay studies ani Holocaust studies. Zniknęła też z eseju Susan Sontag.

25 L. Kramer The Reports from the Holocaust..., s. 239.

26 Tamże, s. 265. 


\section{Abstract}

\section{Grzegorz Niziołek}

JAGIELLONIAN UNIVERSITY (CRACOW)

The Forgotten Metaphor of AIDS

Taking Susan Sontag's incomplete exploration of the cluster of AIDS-related metaphors as a point of departure, Niziołek juxtaposes the view of the AIDS crisis as a'plague' with the metaphor of the Holocaust, which gay rights activists used as a tool to mobilize an active political stance in the fight against the epidemic. Niziołek examines the significance of this metaphor on the psychological, historical and political level.

\section{Keywords}

metaphor, AIDS, Holocaust, Larry Kramer, the American gay rights movement 